\title{
Abdominal Adhesion Prevention: Still a Sticky Subject?
}

\author{
Chris I.W. Lauder Giuseppe Garcea Andrew Strickland Guy J. Maddern \\ University of Adelaide Discipline of Surgery, The Queen Elizabeth Hospital, Woodville, S.A., Australia
}

\section{Key Words}

Adhesions $\cdot$ Peritoneum $\cdot$ Adhesion barrier $\cdot$ Adhesion

prevention $\cdot$ Abdominal surgery

\begin{abstract}
Background: Adhesion formation remains an almost inevitable consequence of abdominal procedures, potentially resulting in significant morbidity and mortality. There is an ongoing need to evaluate current understanding of adhesion formation and products aimed at prevention. Failure to keep up to date with adhesion treatment may subject clinicians to a greater medico-legal risk. Design: Review of published studies exploring the problem of peritoneal adhesion formation. This encompasses the underlying processes of adhesion formation combined with general approaches to reduce formation. An overview of products trialled to prevent formation in both the animal model and clinical setting describes products of scientific interest and commercial success. Results: Advances in surgical technique, such as laparoscopic surgery, can help minimize the probability of adhesion formation. Currently barrier products, whilst reducing adhesion formation, have not been shown to reduce the risk of readmission with complications related to adhesions. Hybrid products may improve upon this situation. Conclusions: No single approach has been wholly satisfactory in reducing adhesions. Research into the processes driving adhesion formation is providing exciting new targets for therapeutic agents. It would seem plausible that with many promising avenues of research a revolutionary agent to reduce the incidence of adhesional small bowel obstruction may result.
\end{abstract}

Copyright $\odot 2010$ S. Karger AG, Basel

\section{KARGER}

Fax +4161306 1234

E-Mail karger@karger.ch

www.karger.com
(C) 2010 S. Karger AG, Basel

0253-4886/10/0275-0347\$26.00/0

Accessible online at:

www.karger.com/dsu

\section{Introduction}

Adhesion formation following surgery remains an almost inevitable consequence of most abdominal procedures. Studies have found the incidence of adhesions to be as high as $95 \%$ [1]. Though surgeons are aware of adhesions and the problems that can result, it seems that few routinely take measures to reduce their formation. Advances in surgical technique, such as the use of laparoscopic surgery, can help minimize the probability of adhesion formation [2]. However, the significant morbidity and cost associated with adhesion-related disorders continues to be highly prevalent. Estimates on the workload for the treatment of adhesion-related disorders have put the annual cost in the USA at around USD 1.3 billion [3]. Undoubtedly, these figures will continue to increase with the growing cost of health care and medico-legal repercussions of adhesion-related complications. Whilst many methods have been employed in an attempt to reduce the formation of adhesions, no single approach has been wholly satisfactory. A concerted effort is required from all branches of medical science and surgery if the problem of adhesions is to be conquered. Continued ignorance of the subject, or a failure to adopt new practices aimed at adhesion prevention is simply not acceptable in the current litigious healthcare environment.
Prof. G.J. Maddern

University of Adelaide Discipline of Surgery, The Queen Elizabeth Hospital

28 Woodville Road

Woodville South, S.A. 5011 (Australia)

Tel. +61 88222 6756, Fax +61 88222 6028, E-Mail guy.maddern@ adelaide.edu.au 


\section{Consequences of Abdominal Adhesions}

The development of intra-abdominal adhesions may manifest in a number of ways and can be categorized as primary or secondary. In primary instances, patients who would not have otherwise required operative intervention require surgery to treat adhesive small bowel obstruction $[4,5]$, volvulus or chronic abdominal pain [6]. In patients with secondary problems from adhesions, future surgery (for abdominal pathology other than adhesions) may be complicated [7] or prolonged [8, 9]. In such cases, the number and density of adhesions will have a direct impact on the second surgical procedure. In female patients, adhesions within the pelvis may result in infertility $[10,11]$, ectopic gestation [12] and chronic pelvic pain $[13,14]$.

Patients undergoing surgery for symptomatic adhesions may also require repeat operations, with each instance associated with an increasing risk of morbidity. Repeated bowel resection or enterotomy as a result of adhesion surgery exposes patients to the risk of anastomotic leak and can increase the chances of developing a variety of other chronic conditions such as short bowel syndrome [15] or enterocutaneous fistulae [16]. Recurrent adhesion-forming patients are perhaps the group with the most to gain from adhesion prevention to break the cycle of re-formation.

Although there is a wide spectrum of adhesive response, the clinically relevant outcome is dependent on patient symptoms or the need for operative intervention. It is difficult to identify individual patients with an increased risk of developing symptomatic adhesions since the relationship between adhesion formation and the surgical pathologies that occur as a consequence is somewhat variable. Logic would dictate that a greater number of adhesions should cause more symptoms; however, this is not always the case. Surgeons will be familiar with the scenario of a single band adhesion causing small bowel obstruction in an otherwise unremarkable abdomen.

\section{Pathogenesis of Adhesion Formation}

Adhesions should be considered as highly cellular, vascularized and dynamic structures under the influence of complex signaling pathways. The idea of an adhesion being a simple nonfunctioning scar is an outdated concept [17]. It is now understood why many of the processes occur in response to an initial adhesion-stimulating event. Damage to the peritoneal mesothelium promotes an acute inflammatory response, with subsequent pathways dictating the number and strength of the fibrous adhesions that form (fig. 1). The mechanisms responsible for a change in normal peritoneal healing to those where adhesions propagate are complex.

Fibrinolysis and extracellular matrix remodeling may be as important in regulating the adhesive process as controlling inflammation in the early stages. The difficulty in modulating adhesion formation lies in separating the process of adhesion formation from that of normal wound healing. Studies examining adhesion formation on a genetic level in an animal model have demonstrated that a large number of genes are upregulated at the wound site postoperatively [18]. Further work is required to identify those genes with a specific role in adhesion formation within the profiles already identified.

On a molecular level, the factors determining cell proliferation, migration, differentiation, angiogenesis, apoptosis and host defense will all have an impact on adhesion formation. Targets for the control of these processes include chemokines $[19,20]$ and matrix metalloproteinases [21]. Vascular endothelial growth factor has also been implicated in having an early role in adhesion initiation [22]. Chemokines trigger a signaling cascade which is responsible for adherence of leukocytes to specific sites in the blood vessels and extravasation into different tissue sites. As such, they can recruit leukocytes into inflammatory areas following surgery. Several cytokines are continuously produced by macrophages and fibroblasts entrapped within the fibrin meshwork [23, 24], including TNF- $\alpha$, IL-1, PDGF, EGF and MCP-1, which in turn recruit leukocytes and increase collagen synthesis [25]. As long as these conditions persist, adhesions will proliferate. The driving forces for this are the presence of foreign material, persistent infection or trauma.

\section{Incidence of Adhesions}

Assessing the true incidence of adhesion formation is a very difficult task. Asymptomatic adhesions have little chance of being discovered unless the patient has further abdominal surgery, or is noted to have adhesions at autopsy. Numerous studies have looked at the incidence of adhesion formation in isolation; however, the key outcome measure in terms of health care provision is the risk of readmission following the original procedure. This will include patients who may not have undergone further surgery, but have repeated admissions with adhesion-related complications. Of the studies looking at this 
Fig. 1. Pathways of adhesion formation or

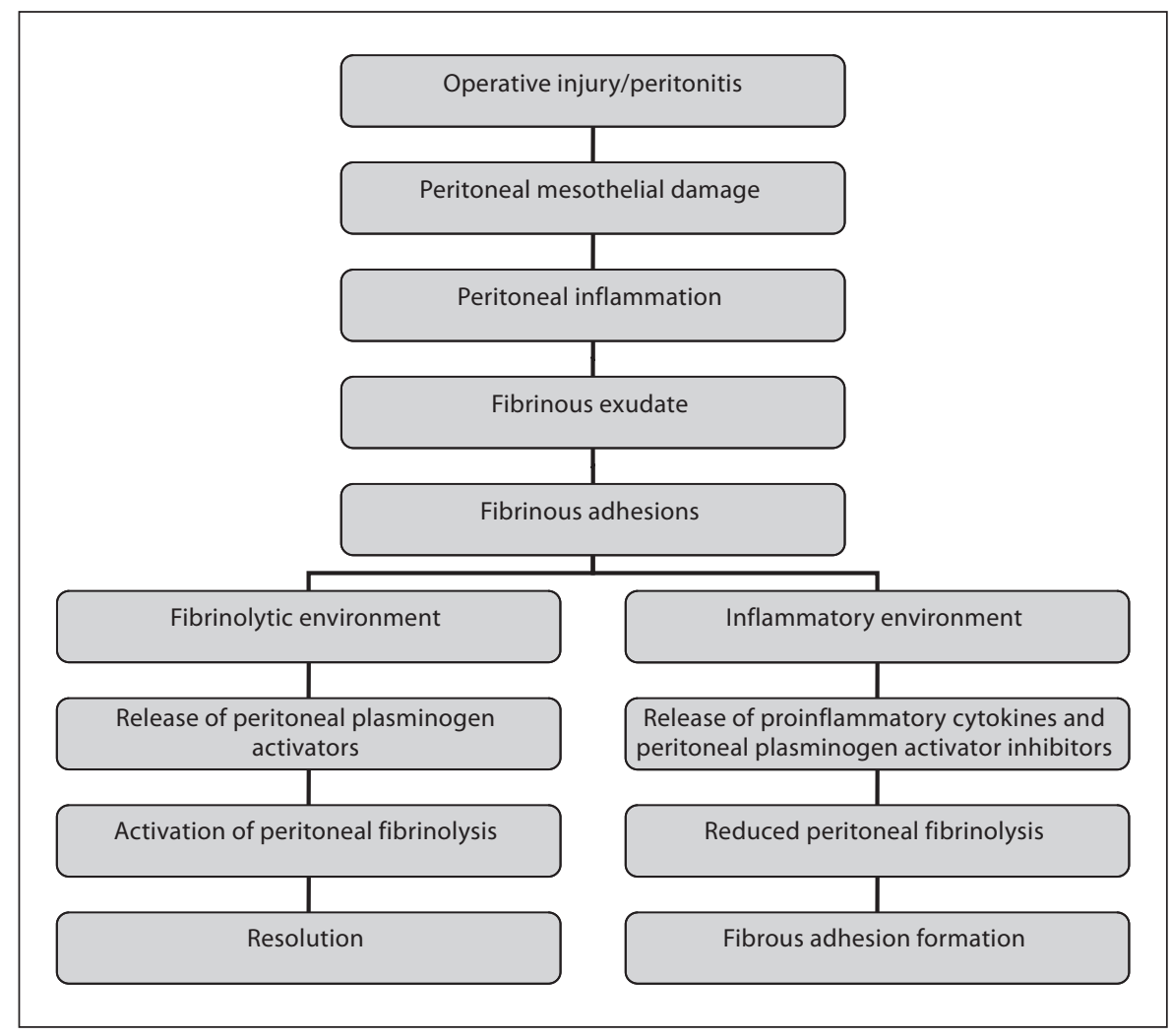

risk, the SCAR-3 study [26] is perhaps the best, following a large cohort of patients for an extended period of time. A 5\% risk of readmission directly related to adhesions in the 5 years following open abdominal surgery (excluding appendicectomy) was demonstrated. In a retrospective American study investigating readmission rates following open colorectal or general surgical procedures, the readmission rate (with a diagnosis of intestinal obstruction) within 2 years ranged from 12.4 to $17 \%$ [4]. Another retrospective study reported proven adhesion-related readmission rates following gynecological surgery at 1.5 to $2 \%$ over a 4 -year period [27]. When admission data included patients with symptoms not proven to be due to adhesions, the figure is substantially higher ranging from 14.5 to $16.1 \%$. This discrepancy highlights the difficulty in isolating iatrogenic adhesion formation in the presence of non-specific symptoms like pain or with coexisting disease such as pelvic inflammatory disease which can produce de novo adhesions. Coding techniques often differ amongst studies which will also have an effect on reporting of patient morbidities.

A final factor in considering the workload associated with the treatment of adhesions is the ageing population.
As the mean survival age increases, the probability of performing more than one surgical procedure on any given patient may also increase.

\section{Models of Adhesion Formation}

The majority of studies investigating adhesion formation utilize an animal model to reproduce surgical insults, although they vary greatly depending on the interests of the investigating party. A lack of uniformity makes collation and interpretation of results between studies difficult. Most models utilize small animals such as the rat or mouse [20, 28-53]; however, the desire to test laparoscopic procedures has necessitated large animal studies [54-56].

The methods used to promote adhesion formation are similarly disparate. Some studies mimic standard surgical procedures on a smaller scale [57], while others use a variety of means to produce much more pronounced adhesions [58]. Although the underlying processes are the same, some stimuli provide a reaction that is unlikely to be replicated in the clinical setting, for example insertion 
of large areas of exposed polypropylene mesh $[44,56,59]$. Results from these 'extreme' models therefore need to be interpreted with caution and their use limited solely to a research tool.

A key issue in assessing adhesions in any context (particularly when assessing therapies to reduce adhesions) is the severity scoring criteria used. Although there has been some agreement between committees on the use of a standardized scoring system for the evaluation of adhesions $[60,61]$, no single method has received widespread acceptance. The two fundamental principles at odds in a method to classify adhesions are those of simplicity versus reproducibility; a scoring system with an infinite number of classifications is unlikely to be popular since it will be difficult to remember, apply and analyze. Conversely, a system that is too simple may fail to demonstrate the difference between treatment arms in adhesion reduction studies, under reporting the true spectrum of disease. Certain criteria would seem essential in the design of adhesion scoring system. The number of sites at which adhesions are present must be recorded as well as noting adhesion length. Further assessment of adhesion strength is necessary, although this can be somewhat subjective. Studies have negated this problem to some degree by using video of procedures to allow an independent observer's interpretation of adhesion strength to be compared with the operating surgeon [62-64]. Typically, the expression of adhesion density starts with filmy adhesions easily taken down by blunt dissection, progressing in density where sharp dissection is required and finally firmly adherent, where no discernable plane is evident.

There are numerous systems based upon these concepts [65-67], although little agreement between studies makes accurate comparison of results difficult. The lack of uniformity between study design and result reporting also makes a meta-analysis of existing data impossible.

\section{Clinical Studies of Adhesion Formation}

Examining adhesion reduction at the surgical site provides a direct measure of the effectiveness of an adhesion prevention regimen; however, few studies have recorded rates of readmission after treatment. To collect accurate data for adhesion-related readmission, the time period needs to be long and the cohort large to demonstrate statistical significance. A study investigating this principle estimated that around 15,000 patients would need to be screened to show a reduced risk of readmission in a trial lasting at least 3.5 years [68]. This is with the assumption that the adhesion reduction product has a $25 \%$ efficacy. Clearly, if a product is more effective, then the numbers of patients required to demonstrate statistical significance would be lower.

Adhesion assessment in the clinical setting does not necessarily require an extra procedure as it can be part of a phased reconstruction such as the reversal of a loop ileostomy [69]. Some gynecological treatment algorithms may also involve a second-look laparoscopy $[63,64,70-$ 72]. In these circumstances, it is possible to directly examine the extent of any adhesions formed.

With the initial use of any new adhesion reduction strategy relook assessment is essential given the quiescent nature of many adhesions. Once the effectiveness of an anti-adhesion agent has been established for a particular surgical operation, longer-term follow-up should confirm the expected effect of a reduced risk of adhesionrelated readmission.

\section{Methods of Adhesion Reduction}

The process of adhesion formation can be thought of as a cycle since failed attempts at adhesion prevention may well lead to further surgical intervention (fig. 2). At each point in this cycle, there is the potential to minimize the formation of adhesions which may be influenced by the following methods.

\section{Surgical Technique}

Since the impact of adhesion-related disorders was realized, there have been numerous attempts to reduce their formation. Changes in surgical technique aim to reduce the trauma associated with a procedure by minimizing tissue handling and practicing meticulous hemostasis. The nidus for persistent inflammation must also be curtailed, including synthetic material such as sutures as well as bacterial soiling, blood or other necrotic material. Aids to achieving these surgical goals include the use of hemostatic agents as well as electrosurgical instruments and laparoscopy. Research investigating the use of specific surgical instruments in isolation have not shown a statistically significant beneficial effect in the reduction of adhesions [73-77]. However, any technique or instrument reducing procedure time, or blood loss, should decrease the physiological insult for the patient, with a reduction in adhesions as a consequence.

Topical products to improve hemostasis have also been shown to provide a beneficial role in reducing adhe- 
Fig. 2. Adhesion cycle and points of manipulation.

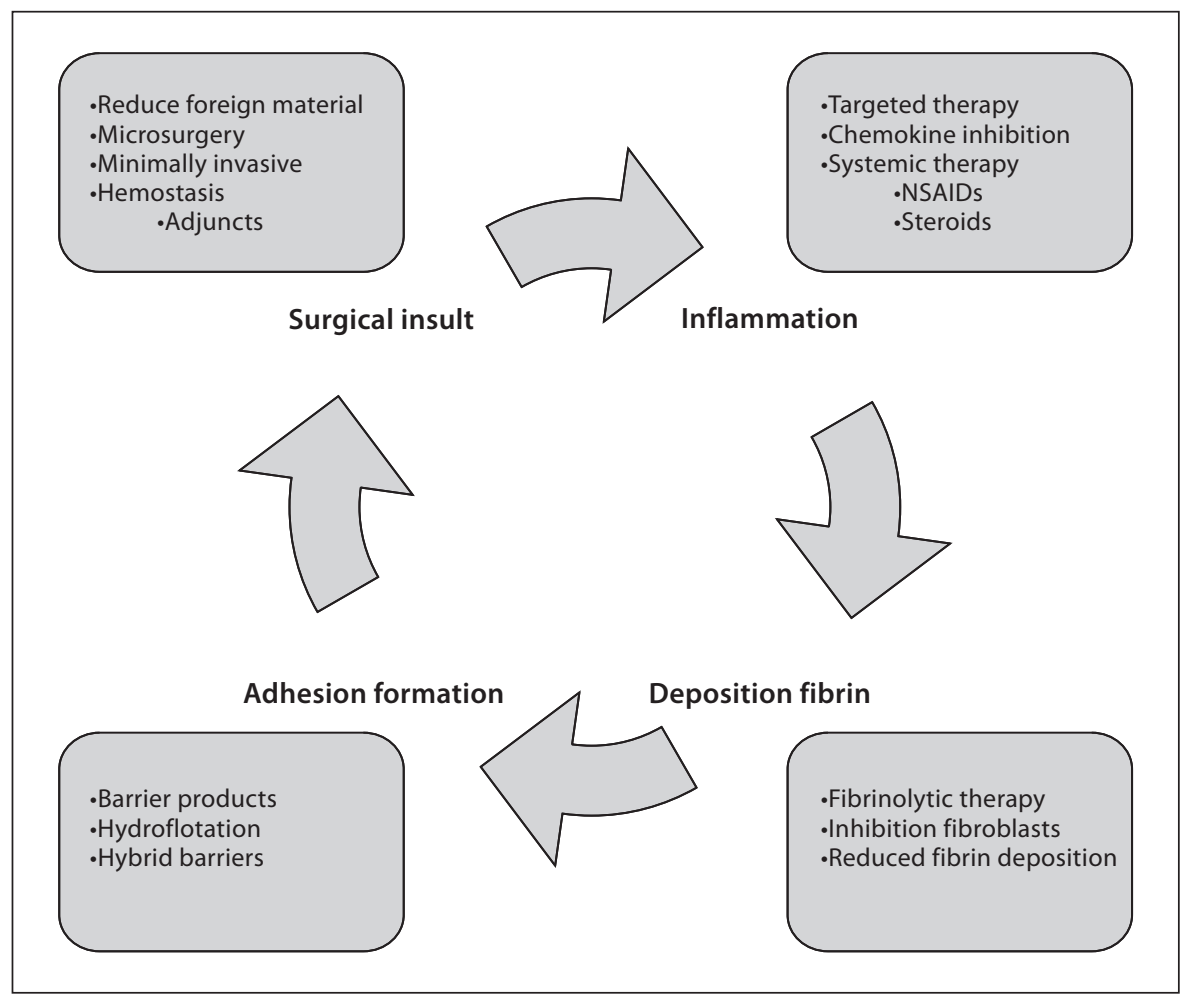

sion formation [78]. Many of the early products used to promote hemostasis show similarities in their composition to adhesion prevention treatments. For example Surgice ${ }^{\circledR}$ (Johnson \& Johnson, Somerville, N.J., USA) consists of oxidized regenerated cellulose. Topical thrombin [79-81] and fibrin [81-83] sealants have evidence to show their efficacy in aiding hemostasis and as such can be thought of as adjuncts in an adhesion reduction strategy.

\section{Laparoscopic versus Open Surgery and Natural}

Orifice Transluminal Endoscopic Surgery

There are many benefits to performing a procedure by the minimally invasive method, though adhesion reduction is often not considered. Good evidence exists supporting a reduction in adhesion formation following laparoscopic surgery for a large number of procedures [54, $55,84,85]$. There are potential disadvantages associated with laparoscopic procedures such as a longer duration of surgery with resulting damage to peritoneal mesothelium from the pneumoperitoneum $[28,29,86,87]$. This is due to a combination of ischemia, acidosis and desiccation. Amelioration of peritoneal damage may be achieved by heating and humidifying the $\mathrm{CO}_{2}$ as well as reducing gas flow rate and insufflation pressures [88-90]. Although some damage to the peritoneum is inevitable, protective measures such as these may allow quicker resolution of any insult.

A variation in the application of minimally invasive surgery has led to the development of natural orifice transluminal endoscopic surgery [91]. It is conceivable that this method may lead to reduced adhesion formation by virtue of the fact that there are no transabdominal ports. However, there is insufficient evidence to support this concept at present [92].

\section{Adhesion Reduction Agents - An Overview}

Adhesion reduction agents can be broadly separated into two categories. The first are the pharmacological therapies given around the time of the patient's operation. The second encompasses topical products applied directly to the operative site.

\section{Pharmacological Therapy}

Many different pharmacological agents have been tried to achieve adhesion reduction [30-43, 93-103]. There is sound logic behind the use of such agents, although their effectiveness has been somewhat limited. 
Reports in the literature describe the effective use of a large number of pharmacological agents in experimental animal studies [30-43, 93, 94, 96, 97, 99-103]. However, few agents progress to clinical trials. The focus of this review is to explore the generic classes of drugs based upon their mode of action within the adhesion formation pathways.

Pharmacological agents have also been applied topically in an attempt to enhance the local effects of the drug. Some systemic absorption is inevitable with drugs administered intraperitoneally, although this is a complex process which depends on the properties of the agent in question. The peritoneum is highly permeable to water, small solutes, and proteins and therefore is not a physical barrier [104]. This porosity can lead to rapid absorption of the agent thus limiting any benefit to intraperitoneal application. No strong evidence exists to suggest that the addition of pharmacological agents to fluid left within the abdomen leads to a reduction in adhesions.

Drugs to mediate the inflammatory response following surgery have been trialled extensively. Initial attempts used steroids [30,93], and nonsteroidal anti-inflammatory drugs [31-33, 94, 95] (NSAIDs). The balance between systemic side effects and adhesion reduction has proved difficult to overcome for this group of agents. The risk of bleeding associated with NSAIDs, or impaired wound healing with steroid use, has limited their use in the clinical setting. More recently, free radical scavengers [34, 96, 97] including methylene blue [105] as well as inhibitors of pro-inflammatory cytokines [35] and antihistamines [36, $37,72-74]$ have been trialled. Although there have been promising results from animal studies, no single agent has progressed to widespread clinical use.

Secondary targets include the processes determining fibrin deposition [38, 98] and fibrinolysis [39, 99-103]. Despite low-dose anticoagulation being the accepted standard for deep vein thrombosis prophylaxis in surgery, the use of therapeutic anticoagulation to reduce fibrin deposition has not been shown to have a statistically significant effect on adhesion reduction. Furthermore, this approach is associated with an increased risk of postoperative bleeding. The alternative approach of promoting fibrinolysis has also been met with concern due to the potential for postoperative bleeding [106].

Adhesion reduction by the inhibition of fibroblast proliferation $[40,41]$ with agents such as mitomycin $C$ has also been trialled, though toxic side effects have limited its use.

Other emerging products include those targeted towards the sites of adhesion formation by inhibition of chemokines. Experimental studies of broad-spectrum chemokine blockade have demonstrated a reduction in adhesion formation in the murine model [42]. Further selective chemokine inhibition such as the prevention of CCL1-CCR8 interaction [43] has also been shown to be effective in experimental models, although clinical trials are awaited.

\section{Topical Products}

The topical products utilized in prevention of intraabdominal adhesions can be divided into two basic categories. The first consists of liquids which are instilled to the abdominal cavity at the end of the operation. Liquids rely on the principal of flotation - since the bowel is freely floating within the abdominal cavity and thus separated to some degree. The simplest form of this method was the application of Ringer's lactate or other crystalloid fluid [107]. There is no significant evidence to support adhesion reduction with this method since the fluid is rapidly absorbed before any surgical injury has healed. Modification of this principle led to the addition of solutes to the fluid to decrease the rate at which absorption occurs. The resultant products are similar to peritoneal dialysis solutions, and have shown some promise in adhesion prevention $[108,109]$.

The second category of topical products consists of gels or films. The basic principle is the separation of the operative surfaces with a mechanical barrier. The barrier must be retained for a suitably long period of time for the surgical insult to heal sufficiently so that adhesions will not form. In order to achieve this, there are certain properties that the product must display. For reabsorbtion to occur, the material must be easily degraded without a fibrous reaction. Popular constituents which meet this criteria include viscous polysaccharides such as cellulose, chitosan, dextran or hyaluronic acid. Interestingly, chitosan, a naturally occurring polysaccharide formed from the deacetylation of chitin, has also been shown to have other beneficial properties that make it a desirable constituent for use in an adhesion prevention product. One aspect is the hemostatic nature of chitosan, with successful use in dressings $[110,111]$ which are now issued to US army personnel. Another is the antimicrobial action of chitosan to a variety of bacteria, fungi and viruses [112]. Chitosan has shown promising results in animal studies as an adhesion prevention product $[51,58]$. Synthetic alternatives include polylactic acid or polyethylene glycol. There is little to choose between these basic materials, although subtle modification of their form may have a significant effect on the polymer properties. 
Some crossover exists between gels and films, many of the films taking on more of a gel type consistency during reabsorption. The exception is the application of a PTFE $\left(G\right.$ oretex ${ }^{\circledR}$ ) film between the injured peritoneal surfaces. Whilst results describing the use of PTFE films have been encouraging [113-115], the application of a nonabsorbable foreign body within the abdomen has been criticized. Not only because of the need for later removal (although this has been debated) but also the potential for chronic infection and difficulty associated with fixation of the film to prevent migration.

\section{Modification of Surgical Materials}

Another challenge to adhesion prevention is the presence of a foreign body such as nonabsorbable sutures or mesh. Coating of the latter has shown some success [44, $56,59]$ in applications where a side of the mesh will potentially come into contact with the bowel. Evaluation of six commercially available meshes in an experimental model showed the absorbable layers of Parietex Composite ${ }^{\circledR}$ and C-Qur ${ }^{\circledR}$ were effective at reducing adhesions in the short term. However, as the absorbable layer was phagocytosed from the mesh, the adhesions reduction was seen to diminish [118]. The simple solution is to avoid or minimizes the use of nonabsorbable materials within the abdomen whenever possible. When this is unavoidable, using adhesion reduction products to isolate the operative site may help to reduce adhesions in the immediate postoperative period. However, suture material is frequently found at the site of important vascular or enteric anastomosis, where an adhesion response is essential in order to reduce the probability of subsequent anastomotic leakage. As such, isolation of the area may be the best compromise.

\section{Evidence-Based Use of Adhesion Prevention Products}

An abundance of published literature describing the use of adhesion reduction products exists; however, the number of good quality randomized control trials is somewhat less. Products that have had the most documented success in humans are the absorbable gels and films. Although the use of some agents is not without certain caveats (such as the avoidance of wrapping the product around any anastomosis, and ensuring complete hemostasis), randomized control trials have shown statistically significant benefits in their ability to reduce adhesion formation [117-125]. As such, the predominance of evidence would suggest that unless there are any contraindications, the surgeon should consider using hyaluronic acid/carboxymethyl membranes. This is of particular rel- evance in patients undergoing staged surgery. Unfortunately, despite a proven reduction in the incidence, extent and severity of adhesions, a decrease in the incidence of intestinal obstruction or need for operative intervention has yet to be shown [126].

A tabulated summary of those products which have been commercially marketed with proven clinical effectiveness is shown in table 1. This gives the opportunity for a rapid review of a product's constituents, any adverse outcomes, and the evidence supporting its use.

\section{Considerations for the Use of Adhesion Prevention Products}

The choice of product used may be influenced by the mode of application. Films/solid membranes may prove difficult to apply laparoscopically. An alternative is an in situ cross-linkable hydrogel that can be applied as a liquid which rapidly gels at the desired site of action. There is no one product that is currently available without certain drawbacks. This may be a result of a sensitivity to the product itself, for example with Hyskon ${ }^{\circledR}$ where patients reacted to the antigenic properties of the constituents [127]. Alternatively, the product may increase the incidence of anastomotic leakage or wound dehiscence such as with Intergel ${ }^{\circledR}$. Adverse outcomes during clinical studies were considered serious enough to cause a product recall $[124,128]$. Other instances where an increased risk of anastomotic leakage has been observed are with the use of Seprafilm ${ }^{\circledR}$. Although the increase in leak rate was relatively low [114], the manufacturers now recommend avoiding wrapping the product around anastomoses. Clinical trials using Interceed $^{\circledR}$ observed that unless complete hemostasis was achieved prior to the application of the product, it may actually precipitate adhesion formation [129].

More minor problems associated with the use of adhesion prevention products center around their application. Many of the more solid sheet preparations require fixation. This makes laparoscopic use a challenge and may necessitate the use of suture material which itself can act as a nidus for adhesion formation. The opposite is true for liquid preparations where the challenge is to keep the solution within the abdomen without leakage from the surgical site. Product storage can be difficult if refrigeration or heating is required prior to use, with specialized applicators using compressed gas or the need for a dedicated light source also deterring routine use. 
Table 1. Adhesion-reducing products

\begin{tabular}{|c|c|c|c|c|}
\hline $\begin{array}{l}\text { Brand name } \\
\text { (Company) }\end{array}$ & Composition and properties & Adverse issues & Current availability & $\begin{array}{l}\text { Evidence } \\
\text { [ref.] }\end{array}$ \\
\hline $\begin{array}{l}\text { Adcon-P } \\
\text { (Gliatech, Inc.) }\end{array}$ & $\begin{array}{l}\text { Gelatin/proteoglycan } \\
\text { Hydrophilic, bioresorbable }\end{array}$ & FDA recalled related product Adcon-L & Animal studies only as of 2003 & 46,47 \\
\hline $\begin{array}{l}\text { Adept } \\
\text { (Innovata) }\end{array}$ & $\begin{array}{l}4 \% \text { icodextrin solution } \\
\text { Hydrophilic, peritoneal residence time }>4 \\
\text { days }\end{array}$ & $\begin{array}{l}\text { Leakage of fluid from the surgical } \\
\text { wound, and abdominal distension/ } \\
\text { discomfort, pulmonary effusion }\end{array}$ & $\begin{array}{l}\text { FDA approved for gynecological } \\
\text { laparoscopic procedures in } \\
\text { August } 2006 \text {, marketed in } \\
\text { Europe for general and } \\
\text { gynecological surgery }\end{array}$ & 108,109 \\
\hline $\begin{array}{l}\text { FloGel (Alliance } \\
\text { Pharm, Co.) }\end{array}$ & $\begin{array}{l}\text { Poloxamer } 407 \\
\text { Hydrophilic, thermosensitive, bioresorbable }\end{array}$ & Requires refrigeration & Early clinical trials & 48,49 \\
\hline $\begin{array}{l}\text { FocalGel } \\
\text { (Focal) }\end{array}$ & $\begin{array}{l}\text { Polyethylene glycol and polylactic acid } \\
\text { Photo-cross-linkable; bioresorbable }\end{array}$ & Requires dedicated light source & $\begin{array}{l}\text { Marketed for general surgical } \\
\text { use }\end{array}$ & 50 \\
\hline $\begin{array}{l}\text { Hyskon } \\
\text { (Medisan } \\
\text { Pharma- } \\
\text { ceuticals) }\end{array}$ & $\begin{array}{l}\text { Dextran } 70 \\
\text { Hydrophilic, bioresorbable }\end{array}$ & $\begin{array}{l}\text { Local and systemic side effects due to } \\
\text { osmotic and antigenic properties } \\
\text { Not sufficient evidence of clinical } \\
\text { effectiveness }\end{array}$ & Indicated as hysteroscopy fluid & $\begin{array}{l}127 \\
131-133\end{array}$ \\
\hline Incert (Anika) & $\begin{array}{l}\text { Chemically crosslinked hyaluronic acid } \\
\text { Hydrophilic, bioresorbable }\end{array}$ & Difficult laparoscopic application & $\begin{array}{l}\text { Pilot human trials in the UK } \\
\text { from } 2004 \text {, Incert-S marketed } \\
\text { for spinal surgery }\end{array}$ & 134 \\
\hline $\begin{array}{l}\text { Interceed } \\
\text { (Ethicon) }\end{array}$ & $\begin{array}{l}\text { Oxidized regenerated cellulose membrane } \\
\text { Hydrophilic, absorbed within } 3-10 \text { days }\end{array}$ & $\begin{array}{l}\text { Limited effectiveness in the presence } \\
\text { of blood and peritoneal fluids }\end{array}$ & $\begin{array}{l}\text { Marketed for general surgical } \\
\text { use }\end{array}$ & $\begin{array}{l}66,67 \\
135,136\end{array}$ \\
\hline $\begin{array}{l}\text { Intergel } \\
\text { (Lifecore) }\end{array}$ & $\begin{array}{l}0.5 \% \text { ferric hyaluronate gel } \\
\text { Hydrophilic, elimination half-life within the } \\
\text { peritoneum } 51 \mathrm{~h}\end{array}$ & $\begin{array}{l}\text { Withdrawn from clinical studies due } \\
\text { to high morbidity associated with } \\
\text { postoperative peritonitis/anastomotic } \\
\text { leak. } \\
\text { Clinical study discontinued }\end{array}$ & Discontinued & $\begin{array}{l}124,128, \\
137\end{array}$ \\
\hline $\begin{array}{l}\text { NOCC } \\
\text { (Kytogenics) }\end{array}$ & $\begin{array}{l}\text { N,O-carboxymethyl chitosan } \\
\text { Hydrophilic, bioresorbable }\end{array}$ & $\begin{array}{l}\text { Pilot clinical trial demonstrated no } \\
\text { significant difference between } \\
\text { treatment and control groups }\end{array}$ & Phase III clinical trial (2002) & $\begin{array}{l}51,52 \\
64\end{array}$ \\
\hline $\begin{array}{l}\text { Preclude } \\
\text { (W.L. Gore) }\end{array}$ & $\begin{array}{l}\text { Expanded polytetrafluoroethylene } \\
\text { membrane } \\
\text { Hydrophobic, not biodegradable }\end{array}$ & $\begin{array}{l}\text { Requires strict sterility and fixation; } \\
\text { difficult to use laparoscopically and } \\
\text { leaves foreign body in the peritoneum }\end{array}$ & $\begin{array}{l}\text { Marketed mainly for } \\
\text { gynecological surgery }\end{array}$ & $113-115$ \\
\hline $\begin{array}{l}\text { Repel (Life } \\
\text { Medical } \\
\text { Sciences) }\end{array}$ & $\begin{array}{l}\text { Polyethylene glycol and polylactic acid block } \\
\text { copolymer membrane } \\
\text { Bioresorbable }\end{array}$ & $\begin{array}{l}\text { Needs fixation; difficult to use } \\
\text { laparoscopically }\end{array}$ & $\begin{array}{l}\text { Repel-CV FDA approved in } \\
\text { March } 2009 \text { for cardiac surgery }\end{array}$ & 138,139 \\
\hline $\begin{array}{l}\text { Sepracoat } \\
\text { (Genzyme) }\end{array}$ & $\begin{array}{l}\text { Sodium hyaluronate solution } \\
\text { Hydrophilic, elimination half-life within the } \\
\text { peritoneum: } 26 \mathrm{~h}\end{array}$ & $\begin{array}{l}\text { Insufficient evidence of clinical } \\
\text { effectiveness }\end{array}$ & $\begin{array}{l}\text { Marketed in Europe for general } \\
\text { surgical use } \\
\text { (Not FDA approved) }\end{array}$ & 140 \\
\hline $\begin{array}{l}\text { Seprafilm } \\
\text { (Genzyme) }\end{array}$ & $\begin{array}{l}\text { Hyaluronic acid-carboxymethylcellulose } \\
\text { membrane } \\
\text { Hydrophilic, absorbed within } 2 \text { weeks }\end{array}$ & $\begin{array}{l}\text { Requires careful handling at open } \\
\text { operation; difficult to use } \\
\text { laparoscopically }\end{array}$ & Marketed for general surgery use & $\begin{array}{l}117-123, \\
125\end{array}$ \\
\hline $\begin{array}{l}\text { Sepragel } \\
\text { (Genzyme) }\end{array}$ & $\begin{array}{l}\text { Hyaluronic acid-carboxymethylcellulose gel } \\
\text { Hydrophilic, bioresorbable }\end{array}$ & $\begin{array}{l}\text { Sepragel spine withdrawn from clinical } \\
\text { trials } 2002\end{array}$ & $\begin{array}{l}\text { Indicated for ENT surgery as a } \\
\text { space-occupying gel }\end{array}$ & 67 \\
\hline $\begin{array}{l}\text { SprayGel } \\
\text { (Confluent } \\
\text { surgical) }\end{array}$ & $\begin{array}{l}\text { In situ cross-linkable polyethylene glycol gel } \\
\text { Hydrophilic, bioresorbable in } 6 \text { days }\end{array}$ & $\begin{array}{l}\text { Requires a specialized applicator and } \\
\text { air supply }\end{array}$ & Marketed for general surgery use & 63,68 \\
\hline $\begin{array}{l}\text { Surgiwrap } \\
\text { sheet (MAST } \\
\text { Biosurgery) }\end{array}$ & $\begin{array}{l}\text { Polylactide membrane } \\
\text { Hydrophobic, bioresorbable in } 24 \text { weeks }\end{array}$ & Needs fixation & $\begin{array}{l}\text { FDA approved in May 2005, also } \\
\text { marketed in Europe for general } \\
\text { surgical use }\end{array}$ & 53 \\
\hline
\end{tabular}




\section{Discussion}

Surgery in its essence is a rather 'blunt tool', injuring the tissues and organs at the operative site. In order for the body to recover from this injury, there must be an adequate healing response. For the most part, this response is a normal part of wound healing with a number of factors differentiating between resolution and pathological adhesion formation. Targeted molecular-level therapy provides an attractive panacea to the problem of adhesions; however, the reality may be somewhat different. Overmodulation of the mechanisms driving this response may lead to an inadequate reaction resulting in complications such as bleeding, anastomotic leak or even local cancer recurrence.

Any product designed to reduce adhesions may be overwhelmed if the stimulating adhesive process is on a massive scale, for example gross fecal contamination of the abdominal cavity. In this context, any product used to modulate the formation of adhesions may be ineffective despite attempts to minimize bacterial soiling at the time of the operation. Patients who are systemically unwell often have a number of other clinical problems, such as coagulopathies, which contribute to the difficulty of adhesion reduction in the acute setting. Such extreme circumstances are difficult to replicate in the research setting since animal models will often not survive them.
No product will be a substitute for good surgical technique, and the best approach to adhesion reduction will be a combination of treatments designed to minimize the adhesion-forming process from the outset. Whilst it is not possible to recommend one specific product for every situation, a number of therapies are currently available that have a good evidence base for their use and should be considered by the operating surgeon. Foresight is required to ensure that products are available at the time of elective surgery so that an opportunity to reduce adhesions is not missed. It is a duty of care that surgeons should be aware of a suitable adhesion reduction strategy relevant to their practice. Failing to discuss adhesions with patients during the consent process is to pave the way for potential negligence claims [130].

Continuing research is providing advances in the field which promise more effective products in adhesion reduction. Barrier gels or films can now be modified to include new pharmacological agents [45] further modulating the adhesion-forming process. Such hybrid solutions may provide a synergistic effect to overcome adhesion formation in most settings. As these new therapies emerge, they will clearly require thorough validation in their use to ensure that patient safety is not compromised.

\section{References}

$\checkmark 1$ Menzies D, Ellis H: Intestinal obstruction from adhesions - how big is the problem? Ann R Coll Surg Engl 1990;72:60-63

$\checkmark 2$ Gutt CN, Oniu T, Schemmer P, et al: Fewer adhesions induced by laparoscopic surgery? Surg Endosc 2004;18:898-906.

$\checkmark 3$ Ray NF, Denton WG, Thamer M, et al: Abdominal adhesiolysis: inpatient care and expenditures in the United States in 1994. J Am Coll Surg 1998;186:1-9.

4 Beck DE, Opelka FG, Bailey HR, et al: Incidence of small-bowel obstruction and adhesiolysis after open colorectal and general surgery. Dis Colon Rectum 1999;42:241-248; erratum in Dis Colon Rectum 1999;42:578.

$\checkmark 5$ Ellis H: The clinical significance of adhesions: focus on intestinal obstruction. Eur J Surg Suppl 1997;577:5-9.

6 Sulaiman H, Gabella G, Davis C, et al: Presence and distribution of sensory nerve fibers in human peritoneal adhesions. Ann Surg 2001;234:256-261.

7 Van Der Krabben AA, Dijkstra FR, Nieuwenhuijzen $\mathrm{M}$, et al: Morbidity and mortality of inadvertent enterotomy during adhesiotomy. Br J Surg 2000;87:467-471.
8 Beck DE, Ferguson MA, Opelka FG, et al: Effect of previous surgery on abdominal opening time. Dis Colon Rectum 2000;43:17491753.

$\checkmark$ Coleman MG, McLain AD, Moran BJ: Impact of previous surgery on time taken for incision and division of adhesions during laparotomy. Dis Colon Rectum 2000;43: 1297-1299.

10 Marana R, Rizzi M, Muzii L, et al: Correla tion between the American Fertility Society classifications of adnexal adhesions and distal tubal occlusion and reproductive outcome in tubal surgery. Fertil Steril 1995;64: 924-929.

-11 Stovall TG, Elder RF, Ling FW: Predictors of pelvic adhesions. J Reprod Med 1989;34: 345-348.

12 Liakakos T, Thomakos N, Fine PM, et al: Peritoneal Adhesions: Etiology, Pathophysiology, and Clinical Significance. Dig Surg 2001;18:260-273.

13 Duffy DM, diZerega GS: Adhesion controversies: pelvic pain as a cause of adhesions, crystalloids in preventing them. J Reprod Med 1996;41:19-26.
14 Howard FM: The role of laparoscopy in chronic pelvic pain: promise and pitfalls. Obstet Gynecol Surv 1993;48:357-387.

15 Thompson JS, DiBaise JK, Iyer KR, et al: Postoperative short bowel syndrome. J Am Coll Surg 2005;201:85-89.

16 van Goor H: Consequences and complications of peritoneal adhesions. Colorectal Dis 2007;9(suppl 2):25-34.

17 Cheong YC, Laird SM, Li TC, et al: Peritoneal healing and adhesion formation/reformation. Hum Reprod Update 2001;7:556-566.

$>18$ Yu SL, Singh S, Chen HW, et al: Intra-abdominal adhesion formation induces antioxidative injury, enhances cell proliferation, and prevents complement-mediated lysis. Wound Repair Regen 2008;16:388-398.

19 Chegini N, Rong H, Bennett B, et al: Peritoneal fluid cytokine and eicosanoid levels and their relation to the incidence of peritoneal adhesion. J Soc Gynecol Investig 1999;6:153157.

20 Hoshino A, Kawamura YI, Yasuhara M, et al: Inhibition of CCL1-CCR8 interaction prevents aggregation of macrophages and development of peritoneal adhesions. J Immunol 2007; 178:5296-5304. 
21 Chegini N, Kotseos K, Zhao Y, et al: Expression of matrix metalloproteinase (MMP-1) and tissue inhibitor of MMP in serosal tissue of intraperitoneal organs and adhesions. Fertil Steril 2001;76:1212-1219.

-22 Cahill RA, Wang JH, Soohkai S, Redmond HP: Mast cells facilitate local VEGF release as an early event in the pathogenesis of postoperative peritoneal adhesions. Surgery 2006; 140:108-112

23 Kovacs EJ, DiPietro LA: Fibrogenic cytokines and connective tissue production. FASEB J 1994;8:854-861.

24 Zeyneloglu HB, Senturk LM, Seli E, et al: The role of monocyte chemotactic protein-1 in intraperitoneal adhesion formation. Hum Reprod 1998;13:1194-1199.

25 Kovacs EJ: Fibrogenic cytokines: the role of immune mediators in the development of scar tissue. Immunol Today 1991;12:17-23.

-26 Parker MC, Wilson MS, Menzies D, et al: The SCAR-3 study: 5-year adhesion-related readmission risk following lower abdominal surgical procedures. Colorectal Dis 2005;7:551558.

27 Lower AM, Hawthorn RJ, Ellis H, et al: The impact of adhesions on hospital readmissions over ten years after 8,849 open gynaecological operations: an assessment from the Surgical and Clinical Adhesions Research Study. BJOG 2000;107:855-862.

28 Molinas CR, Mynbaev O, Pauwels A, et al: Peritoneal mesothelial hypoxia during pneumoperitoneum is a cofactor in adhesion formation in a laparoscopic mouse model. Fertil Steril 2001;76:560-567.

-29 Rosário MT, Ribeiro U Jr, Corbett CE, et al: Does $\mathrm{CO}_{2}$ pneumoperitoneum alter the ultra-structuture of the mesothelium? J Surg Res 2006;133:84-88.

30 Höckel M, Ott S, Siemann U, et al: Prevention of peritoneal adhesions in the rat with sustained intraperitoneal dexamethasone delivered by a novel therapeutic system. Ann Chir Gynaecol 1987;76:306-313.

- 31 LeGrand EK, Rodgers KE, Girgis W, et al: Efficacy of tolmetin sodium for adhesion prevention in rabbit and rat models. J Surg Res 1994;56:67-71.

- 32 Guvenal T, Cetin A, Ozdemir H, et al: Prevention of postoperative adhesion formation in rat uterine horn model by nimesulide: a selective COX-2 inhibitor. Hum Reprod 2001;16:1732-1735.

33 De Leon F, Toledo A, Sanfilippo J, et al: The prevention of adhesion formation by nonsteroidal antiinflammatory drugs: an animal study comparing ibuprofen and indomethacin. Fertil Steril 1984;41:639-642.

- 34 de la Portilla F, Ynfante I, Bejarano D, et al: Prevention of peritoneal adhesions by intraperitoneal administration of vitamin E: an experimental study in rats. Dis Colon Rectum 2005;47:2157-2161.
35 Lucas P, Warejcka D, Young H, et al: Formation of abdominal adhesions is inhibited by antibodies to transforming growth factorbeta1. J Surg Res 1996;65:135-138.

-36 Avsar F, Sahin M, Aksoy F, et al: Effects of diphenhydramine $\mathrm{HCl}$ and methylprednisolone in the prevention of abdominal adhesions. Am J Surg 2001;181:512-515.

-37 Replogle RL, Johnson R, Gross RE: Prevention of postoperative intestinal adhesions with combined promethazine and dexamethasone therapy: experimental and clinical studies. Ann Surg 1966;163:580-588.

38 Chowdhury SM, Hubbell JA: Adhesion prevention with ancrod released via a tissue-adherent hydrogel. J Surg Res 1996;61:58-64.

39 Hill-West JL, Dunn RC, Hubbell JA: Local release of fibrinolytic agents for adhesion prevention. J Surg Res 1995;59:759-763.

40 Liu Y, Li H, Shu XZ, SD, et al: Crosslinked hyaluronan hydrogels containing mitomycin $\mathrm{C}$ reduce postoperative abdominal adhesions. Fertil Steril 2005;83(suppl 1):12751283.

41 Cubukcu A, Alponat A, Gonullu N: An experimental study evaluating the effect of $\mathrm{Mi}$ tomycin $\mathrm{C}$ on the prevention of postoperative intraabdominal adhesions. J Surg Res 2001;96:163-166.

42 Berkkanoglu M, Zhang L, Ulukus M, et al: Inhibition of chemokines prevents intraperitoneal adhesions in mice. Hum Reprod 2005;20:3047-3052.

43 Hoshino A, Kawamura YI, Yasuhara M, et al: Inhibition of CCL1-CCR8 interaction prevents aggregation of macrophages and development of peritoneal adhesions. J Immunol 2007;178:5296-5304.

-44 Ansaloni L, Catena F, Coccolini F, et al: Peritoneal adhesions to prosthetic materials: An experimental comparative study of treated and untreated polypropylene meshes placed in the abdominal cavity. J Laparoendosc Adv Surg Tech A 2009;19:369-374.

45 Yeo Y, Ito T, Bellas E, et al: In situ cross-linkable hyaluronan hydrogels containing polymeric nanoparticles for preventing postsurgical adhesions. Ann Surg 2007;245:819-824.

46 Oncel M, Remzi FH, Senagore AJ, et al: Liquid antiadhesive product (Adcon-p) prevents post-operative adhesions within the intraabdominal organs in a rat model. Int $\mathrm{J}$ Colorectal Dis 2003;18:514-517.

47 Oncel M, Remzi FH, Senagore AJ, et al: Application of Adcon-P or Seprafilm in consecutive laparotomies using a murine model. Am J Surg 2004;187:304-308.

48 Leach RE, Henry RL: Reduction of postoperative adhesions in the rat uterine horn model with poloxamer 407. Am J Obstet Gynecol 1990;162:1317-1319.

49 Steinleitner A, Lambert H, Kazensky C, et al: Poloxamer 407 as an intraperitoneal barrier material for the prevention of postsurgical adhesion formation and reformation in rodent models for reproductive surgery. Obstet Gynecol 1991;77:48-52.
50 Hill-West JL, Chowdhury SM, Sawhney AS, et al: Prevention of postoperative adhesions in the rat by in situ photopolymerization of bioresorbable hydrogel barriers. Obstet Gynecol 1994;83:59-64.

-51 Zhou J, Elson C, Lee TD: Reduction in postoperative adhesion formation and re-formation after an abdominal operation with the use of N,O-carboxymethyl chitosan. Surgery 2004;135:307-312.

52 Kennedy R, Costain DJ, McAlister VC, et al: Prevention of experimental postoperative peritoneal adhesions by N,O-carboxymethyl chitosan. Surgery 1996;120:866-870.

53 Avital S, Bollinger TJ, Wilkinson JD, et al: Preventing intra-abdominal adhesions with polylactic acid film: an animal study. Dis Colon Rectum 2005;48:153-157.

54 Chen MD, Teigen GA, Reynolds HT, et al: Laparoscopy versus laparotomy: an evaluation of adhesion formation after pelvic and paraaortic lymphadenectomy in a porcine model. Am J Obstet Gynecol 1998;178:499503.

55 Moore RG, Partin AW, Adams JB, et al: Adhesion formation after transperitoneal nephrectomy: laparoscopic vs open approach. J Endourol 1995;9:277-280

-56 Jacob BP, Hogle NJ, Durak E, et al: Tissue ingrowth and bowel adhesion formation in an animal comparative study: polypropylene versus Proceed versus Parietex Composite. Surg Endosc 2007;21:629-633.

57 Krähenbühl L, Schäfer M, Kuzinkovas V, et al: Experimental study of adhesion formation in open and laparoscopic fundoplication. Br J Surg 1998;85:826-830.

58 Zhang ZL, Xu SW, Zhou XL: Preventive effects of chitosan on peritoneal adhesion in rats. World J Gastroenterol 2006;12:45724577.

-59 Bellón JM, Rodríguez M, García-Honduvilla $\mathrm{N}$, et al: Peritoneal effects of prosthetic meshes used to repair abdominal wall defects: monitoring adhesions by sequential laparoscopy. J Laparoendosc Adv Surg Tech A 2007;17:160-166.

-60 Adhesion Scoring Group. Improvement of interobserver reproducibility of adhesion scoring system. Fertil Steril 1994;62:984988.

61 American Fertility Society. The AFS classification of adnexal adhesions, distal tubal occlusion, tubal occlusion secondary to tubal ligation, tubal pregnancies, Müllerian anomalies and intrauterine adhesions. Fertil Steril 1988;49:944-955.

62 Corson SL, Batzer FR, Gocial B, et al: Intraobserver and inter-observer variability in scoring laparoscopic diagnosis of pelvic adhesions. Hum Reprod 1995;10:161-164.

63 Johns DA, Ferland R, Dunn R: Initial feasibility study of a sprayable hydrogel adhesion barrier system in patients undergoing laparoscopic ovarian surgery. J Am Assoc Gynecol Laparosc 2003;10:334-338. 
64 Diamond MP, Luciano A, Johns DA, et al: Reduction of postoperative adhesions by N,O-carboxymethylchitosan: a pilot study. Fertil Steril 2003;80:631-636.

65 Hulka JF: Adnexal adhesions, a prognostic staging and classification system based on a 5 -year survey of fertility surgery results at Chapel Hill, North Carolina. Am J Obstet and Gynecol 1982;144:141-148.

66 Linsky CB, Diamond MP, Cunningham T, et al: Adhesion reduction in the rabbit uterine horn model using an absorbable barrier, TC7. J Reprod Med 1987;32:17-20.

- 67 Leach RE, Burns JW, Dawe EJ, et al: Reduction of postsurgical adhesion formation in the rabbit uterine horn model with use of hyaluronate/carboxymethylcellulose gel. Fertil Steril 1998;69:415-418

68 Wilson MS: Practicalities and costs of adhesions. Colorectal Dis 2007;9(suppl 2):60-65.

-69 Tjandra JJ, Chan MK: A sprayable hydrogel adhesion barrier facilitates closure of defunctioning loop ileostomy: a randomized trial. Dis Colon Rectum 2008;51:956-960.

-70 Takeuchi H, Kitade M, Kikuchi I, et al: Adhesion prevention effects of fibrin sealants after laparoscopic myomectomy as determined by second look laparoscopy: a prospective randomised, controlled study. J Reprod Med 2005;50:571-577.

-71 Hellebrekers BW, Trimbos-Kemper TC, Boesten L, et al: Preoperative predictors of postsurgical adhesion formation and the Prevention of Adhesions with Plasminogen Activator (PAPA-study): results of a clinical pilot study. Fertil Steril 2009;91:1204-1214.

-72 Mercorio F, Mercorio A, Di Spiezio Sardo A, et al: Evaluation of ovarian adhesion formation after laparoscopic ovarian drilling by second-look minilaparoscopy. Fertil Steril 2008;89:1229-1233.

73 Montgomery TC, Sharp JB, Bellina JH, et al: Comparative gross and histological study of the effects of scalpel, electric knife, and carbon dioxide laser on skin and uterine incisions in dogs. Lasers Surg Med 1983;3:9-22.

74 Bellina JH, Hemmings R, Voros JI, et al: Carbon dioxide laser and electrosurgical wound study with an animal model: a comparison of tissue damage and healing patterns in peritoneal tissue. Am J Obstet Gynecol 1984; 148:327-334

-75 Filmar S, Jetha N, McComb P, et al: A comparative histologic study on the healing process after tissue transection. I. Carbon dioxide laser and electromicrosurgery. Am J Obstet Gynecol 1989;160:1062-1067.

-76 Filmar S, Jetha N, McComb P, et al: A comparative histologic study on the healing process after tissue transection. II. Carbon dioxide laser and surgical microscissors. Am J Obstet Gynecol 1989;160:1068-1072.

-77 Forestier D, Slim K, Joubert-Zakeyh J, et al: Do bipolar scissors increase postoperative adhesions? An experimental double-blind randomized trial. Ann Chir 2002;127:680684. parison of recombinant thrombin to bovin thrombin as a hemostatic ancillary in patients undergoing peripheral arterial bypass and arteriovenous graft procedures. J Vasc Surg 2008;47:1266-1273.

79 Chapman WC, Lockstadt H, Slngla N, et al: Phase 2, randomized, double-blind, placebo-controlled, multicenter clinical evaluation of recombinant human thrombin in multiple surgical indications. J Thromb Haemost 2006;4:2083-2085.

80 Doria C, Fischer CP, Wood CG, et al: Phase 3 , randomized, double-blind study of plasma-derived human thrombin versus bovine thrombin in achieving hemostasis in patients undergoing surgery. Curr Med Res Opin 2008;24:785-794.

81 Levy O, Martinowitz U, Oran A, et al: The use of fibrin tissue adhesive to reduce blood loss and the need for blood transfusion after total knee arthroplasty. A prospective, randomized, multicenter study. J Bone Joint Surg Am 1999;81:1580-1588.

82 Wang GJ, Goldthwaite CA Jr, Burks S, et al: Fibrin sealant reduces perioperative blood loss in total hip replacement. J Long Term Eff Med Implants 2003;13:399-411.

83 Milne AA, Murphy WG, Reading SJ, et al: Fibrin sealant reduces suture line bleeding during carotid endarterectomy: a randomised trial. Eur J Vasc Endovasc Surg 1995;10:91-94.

84 Schäfer M, Krähenb L, Büchler MW: Comparison of adhesion formation in open and laparoscopic surgery. Dig Surg 1998;15:148152.

85 Garrard CL, Clements RH, Nanney L, et al: Adhesion formation is reduced after laparoscopic surgery. Surg Endosc 1999;13:10-13.

-86 Molinas CR, Koninckx PR: Hypoxaemia induced by $\mathrm{CO}_{2}$ or helium pneumoperitoneum is a co-factor in adhesion formation in rabbits. Hum Reprod 2000;15:1758-1763.

87 Kopernik G, Avinoach E, Grossman Y, et al: The effect of a high partial pressure of carbon dioxide environment on metabolism and immune functions of human peritoneal cells-relevance to carbon dioxide pneumoperitoneum. Am J Obstet Gynecol 1998;179: 1503-1510.

88 Sajid MS, Mallick AS, Rimpel J, et al: Effect of heated and humidified carbon dioxide on patients after laparoscopic procedures: a meta-analysis. Surg Laparosc Endosc Percutan Tech 2008;18:539-546.

89 Savel RH, Balasubramanya S, Lasheen S, et al: Beneficial effects of humidified, warmed carbon dioxide insufflation during laparoscopic bariatric surgery: a randomized clinical trial. Obes Surg 2005;15:64-69.

90 Farley DR, Greenlee SM, Larson DR, et al: Double-blind, prospective, randomized study of warmed, humidified carbon dioxide insufflation vs standard carbon dioxide for patients undergoing laparoscopic cholecystectomy. Arch Surg 2004;139:739-743; discussion 743-744.
-91 Flora ED, Wilson TG, Martin IJ, O’Rourke NA, Maddern GJ: A review of natural orifice translumenal endoscopic surgery (NOTES) for intra-abdominal surgery: experimental models, techniques, and applicability to the clinical setting. Ann Surg 2008;247:583-602.

-92 Maddern GJ: NOTES: progress or marketing? ANZ J Surg 2009;79:318-319.

-93 Kucukozkan T, Ersoy B, Uygur D, et al: Prevention of adhesions by sodium chromoglycate, dexamethasone, saline and aprotinin after pelvic surgery. ANZ J Surg 2004; 74:1111-1115

94 Nishimura K, Nakamura R, diZerega G: Ibuprofen inhibition of postsurgical adhesion formation: a time and dose response biochemical evaluation in rabbits. J Surg Res 1984;36:115-124.

95 Holtz G: Failure of a nonsteroidal anti-inflammatory agent (ibuprofen) to inhibit peritoneal adhesion reformation after lysis. Fertil Steril 1982;37:582-583.

96 Binda MM, Molinas CR, Koninckx PR: Reactive oxygen species and adhesion formation: clinical implications in adhesion prevention. Hum Reprod 2003;18:2503-2507.

97 Portz D, Elkins T, White R, et al: Oxygen free radicals and pelvic adhesions formation: I. Blocking oxygen free radical toxicity to prevent adhesion formation in an endometriosis model. Int J Fertil 1991;36:39-42.

98 Reid RL, Lie K, Spence JE, et al: Clinical evaluation of the efficacy of heparin-saturated interceed for prevention of adhesion reformation in the pelvic sidewall of the human; in Diamond MP, diZerega GS, Linsky $\mathrm{CB}$, et al (eds): Gynecologic Surgery and Adhesion Prevention. New York, Wiley, 1993, pp 261-264.

$\checkmark 99$ Dunn RC, Mohler M: Effect of varying days of tissue plasminogen activator therapy on the prevention of postsurgical adhesions in a rabbit model. J Surg Res 1993;54:242-245.

100 Orita H, Fukasawa M, Girgis W, diZerega GS: Inhibition of postsurgical adhesions in a standardized rabbit model: intraperitoneal treatment with tissue plasminogen activator. Int J Fertil 1991;36:172-177.

101 Menzies D, Ellis H: The role of plasminogen activator in adhesion prevention. Surg Gynecol Obstet 1991;172:362-366.

102 Dunn RC, Mohler M: Effect of varying days of tissue plasminogen activator therapy on the prevention of post-surgical adhesions in a rabbit model. J Surg Res 1993;54:242245.

103 Holmdahl LE, Al-Jabreen M, Risberg B: Role of fibrinolysis in the formation of postoperative adhesions. Wound Repair Regen 1994;2:171-176.

104 Flessner MF: The transport barrier in intraperitoneal therapy. Am J Physiol Renal Physiol 2005;288:F433-F442. 
105 Mahdy T, Mohamed G, Elhawary A: Effect of methylene blue on intra-abdominal adhesion formation in rats. Int J Surg 2008;6: 452-455.

106 Chalela JA, Katzan I, Liebeskind DS, et al: Safety of intra-arterial thrombolysis in the postoperative period. Stroke 2001;32:13651369.

-107 Wiseman DM, Trout JR, Diamond MP: The rates of adhesion development and the effects of crystalloid solutions on adhesion development in pelvic surgery. Fertil Steril 1998;70:702-711.

-108 Menzies D, Pascual MH, Walz MK, et al: Use of icodextrin $4 \%$ solution in the prevention of adhesion formation following general surgery: from the multicentre ARIEL Registry. Ann R Coll Surg Engl 2006;88: 375-382.

109 diZerega GS, Verco SJ, Young P, et al: A randomized, controlled pilot study of the safety and efficacy of $4 \%$ icodextrin solution in the reduction of adhesions following laparoscopic gynaecological surgery. Hum Reprod 2002;17:1031-1038.

-110 Ong SY, Wu J, Moochhala SM, et al: Development of a chitosan-based wound dressing with improved hemostatic and antimicrobial properties. Biomaterials 2008;29: 4323-4332.

-111 Gustafson SB, Fulkerson P, Bildfell R, et al: Chitosan dressing provides hemostasis in swine femoral arterial injury model. Prehosp Emerg Care 2007;11:172-178.

-112 Rabea EI, Badawy ME, Stevens CV, et al: Chitosan as antimicrobial agent: applications and mode of action. Biomacromolecules 2003;4:1457-1465.

-113 Haney A, Hesla J, Hurst B, et al: Expanded polytetrafluororethylene (Gore-Tex Surgical Membrane) is superior to oxidized regenerated cellulose (Interceed TC7+) in preventing adhesions. Fertil Steril 1995;63: 1021-1026.

114 Haney A, Hesla J, Hurst B, et al: Prevention of pelvic side wall adhesion reformation using surgical barriers: expanded polytetrafluororethylene (Gore-Tex Surgical Membrane) is superior to oxidized regenerated cellulose (Interceed TC7+) (abstract). Fertil Steril 1994;S210:265.

115 Korell M: Reduction of adhesion by INTERCEED Barrier and Gortex Surgical Membrane after laparoscopic myomectomy; presented at 'Möglichkeiten der Adhäsionsprophylaxe', Munich, April 1994.

-116 Schreinemacher MH, Emans PJ, Gijbels MJ, et al: Degradation of mesh coatings and intraperitoneal adhesion formation in an experimental model. Br J Surg 2009;96:305313.

-117 Diamond MP: Reduction of adhesions after uterine myomectomy by Seprafilm membrane (HAL-F): a blinded, prospective, randomized, multicenter clinical study. Seprafilm Adhesion Study Group. Fertil Steril 1996;66:904-910.
118 Beck DE, Cohen Z, Fleshman JW, et al: A prospective, randomised, multicenter, controlled study of the safety of seprafilm adhesion barrier in abdominopelvic surgery of the intestine. Dis Colon Rectum 2003;46: 1310-1319.

119 Becker JM, Dayton MT, Fazio VW, et al: Prevention of postoperative abdominal adhesions by a sodium hyaluronate based bioresorbable membrane: a prospective, randomised, double-blind multicenter study. J Am Coll Surg 1996;183:297-306.

120 Cohen Z, Senagore A, Dayton M, et al: Prevention of postoperative abdominal adhesions by a novel, glycerol/sodium hyaluronate/carboxymethylcellulose-based bioresorbable membrane: a prospective, randomised, evaluator-blinded multicenter study. Dis Colon Rectum 2005;48: 1130-1139.

121 Fazio VW, Cohen Z, Fleshman JW, et al: Reduction in adhesive small-bowel obstruction by seprafilm ahesion barrier after intestinal resection. Dis Colon Rectum 2006;49:1-11.

122 Kusunoki M, Ikeuchi H, Yanagi H, et al: Bioresorbable hyaluronate-carboxymethylcellulose membrane (Seprafilm) in surgery for rectal carcinoma: a prospective randomised clinical trial. Surg Today 2005; 35:940-945.

123 Tang CL, Seow-Choen F, Fook-Chong S, et al: Bioresorbable adhesion barrier facilitates early closure of the defunctioning ileostomy after rectal excision: a prospective, randomised trial. Dis Colon Rectum 2003; 46:1200-1207.

124 Tang CL, Jayne DG, Seow-Choen F, et al: A randomised controlled trial of $0.5 \%$ ferric hyaluronate gel (Intergel) in the prevention of adhesions following abdominal surgery. Ann Surg 2006;243:449-455.

-125 Vrijland WW, Tseng LNL, Eijkman HJM, et al: Fewer intraperitoneal adhesions with use of hyaluronic acid-carboxymethylcellulose membrane: a randomised clinical trial. Ann Surg 2002;235:193-199.

126 Kumar S, Wong PF, Leaper DJ: Intra-peritoneal prophylactic agents for preventing adhesions and adhesive intestinal obstruction after non-gynaecological abdominal surgery. Cochrane Database Syst Rev 2009;CD005080.

127 Perlitz Y, Oettinger M, Karam K, et al: Anaphylactic shock during hysteroscopy using Hyskon solution: case report and review of adverse reactions and their treatment. Gynecol Obstet Invest 1996;41:67-69.
128 Johns DB, Keyport GM, Hoehler F, et al: Reduction of postsurgical adhesions with Intergel adhesion prevention solution: a multicenter study of safety and efficacy after conservative gynecologic surgery. Fertil Steril 2001;76:595-604.

129 DeCherney AH, diZerega GS: Clinical problem of intraperitoneal postsurgical adhesion formation following general surgery and the use of adhesion prevention barriers. Surg Clin North Am 1997;77:671-688.

130 Ellis H: Medicolegal consequences of adhesions. Hosp Med 2004;65:348-350.

131 Gauwerky JF, Heinrich D, Kubli F: Complications of intraperitoneal dextran application for prevention of adhesions. Biol Res Pregnancy Perinatol 1986;7:93-97.

132 Larsson B, Lalos O, Marsk L, et al: Effect of intraperitoneal instillation of 32\% dextran 70 on postoperative adhesion formation after tubal surgery. Acta Obstet Gynecol Scand 1985;64:437-441.

133 Sites CK, Jensen BA, Glock JL, et al: Transvaginal ultrasonographic assessment of transvaginal ultrasonographic assessment of Hyskon or lactated Ringer's solution instillation after laparoscopy: randomized, controlled study. J Ultrasound Med 1997; 16:195-199.

134 Haney AF, Doty E: A barrier composed of chemically cross-linked hyaluronic acid (Incert) reduces postoperative adhesion formation. Fertil Steril 1998;70:145-151.

135 Nordic Adhesion Prevention Study Group. The efficacy of Interceed (TC7)* for prevention of reformation of postoperative adhesions on ovaries, fallopian tubes, and fimbriae in microsurgical operations for fertility: a multicenter study. Fertil Steril 1995;63:709-714.

$>136$ Adhesion Barrier Study Group. Prevention of postsurgical adhesions by INTERCEED (TC7), an absorbable adhesion barrier: a prospective randomized multicenter clinical study. Fertil Steril 1989;51:933-938.

137 Wiseman DM: Possible intergel reaction syndrome (pIRS). Ann Surg 2006;244:630632 .

138 Okuyama N, Rodgers KE, Wang CY, et al: Prevention of retrosternal adhesion formation in a rabbit model using bioresorbable films of polyethylene glycol and polylactic acid. J Surg Res 1998;78:118-122.

139 Rodgers K, Cohn D, Hotovely A, et al: Evaluation of polyethylene glycol/polylactic acid films in the prevention of adhesions in the rabbit adhesion formation and reformation sidewall models. Fertil Steril 1998;69: 403-408.

140 Diamond MP: Reduction of de novo postsurgical adhesions by intraoperative precoating with Sepracoat (HAL-C) solution: a prospective, randomized, blinded, placebo-controlled multicenter study. The Sepracoat Adhesion Study Group. Fertil Steril 1998;69:1067-1074. 